\title{
Distribution and conservation status of Shortridge's capped langurs Trachypithecus shortridgei in China
}

\author{
Liang-Wei Cui, Ying-Chun Li, Chi Ma, Matthen B. Scott, Jin-Fa Li \\ Xiao-Yang He, Dong-Hui Li, Jun Sun, Wen-Mo Sun and Wen Xiao
}

\begin{abstract}
We conducted community interviews and field surveys to determine the distribution and population of the Endangered Shortridge's capped langur Trachypithecus shortridgei, and the threats to the species, in the Dulong and $\mathrm{Nu}$ River valleys of north-western Yunnan Province, China. We found that c. 19 groups of T. shortridgei reside in the Dulong valley, mostly located in the southern portion of the valley. According to interview and observational records in the Gaoligong Mountains to the west of the Nu River, 12 individuals and no groups were observed. Family groups consist of one adult male, 2-3 adult females and up to five young. We estimate the population of $T$. shortridgei in China to be c. 250-370 individuals. Threats to the species include habitat loss and poaching. We suggest several measures to conserve $T$. shortridgei, such as a review of the Gaoligong National Nature Reserve management strategy, and increasing engagement, education, inclusion of local people in forest management, and the consistency of enforcement.
\end{abstract}

Keywords Endangered species, hunter interviews, local knowledge, population estimation, Shortridge's capped langur, species distribution, Trachypithecus shortridgei

\section{Introduction}

Chortridge's capped langur Trachypithecus shortridgei $\checkmark$ (Wroughton, 1915) is a colobine primate that inhabits low to mid-elevation evergreen and semi-evergreen forests east of the Chindwin River in north-eastern Myanmar,

LIANG-Wei CUI $†$ (Corresponding author), YING-ChUn LI $\dagger$, JiN-FA Li and WeNMo Sun Forestry Faculty, South-west Forestry University, Kunming, Yunnan, 650224, China. E-mail gcuilw@gmail.com

Chi Ma, Matthew B. Scott and Wen Xiao (Corresponding author) Institute of Eastern-Himalaya Biodiversity Research, Dali University, Dali, Yunnan, 671003 , China. E-mail xiaowen.dali@gmail.com

Xiao-Yang He, Dong-Hui Li and Jun Sun Nujiang Administration Bureau, Gaoligongshan National Nature Reserve, Liuku, Yunnan, China

${ }^{*}$ Also at: Key Laboratory of Resource Biology and Biotechnology in Western China, College of Life Sciences, Northwest University, Xi'an, China

$\dagger$ These authors contributed equally to this work.

Received 12 September 2014. Revision requested 8 October 2014.

Accepted 2 March 2015. First published online 29 May 2015. and in south-western China in the $\mathrm{Nu}$ and Dulong valleys (Pocock, 1939; Groves, 2001; Htun et al., 2008). Numbers of individuals are assumed to be low and declining as a result of a restricted geographical range, hunting pressure and widespread deforestation for agriculture and timber extraction. The total population is believed to have declined by at least 50\% since 1972, primarily as a result of hunting and habitat loss (Htun et al., 2008). Consequently, T. shortridgei is categorized as Endangered on the IUCN Red List (Htun et al., 2008) and is listed in CITES Appendix I (CITES, 2014). In China it is a Category I protected species under Chinese animal conservation laws, and in Myanmar it is protected under the national Wildlife Protection Law (Htun et al., 2008).

To achieve more successful management, a better understanding of the species is needed, including population size, distribution, threats, and impediments to its conservation. There are no population data available from Myanmar (Htun et al., 2008), and the distribution and population data from China are outdated and based on scant field data collected using unclear or dubious methodologies. $\mathrm{Li}$ \& Lin (1983) suggested the range of T. shortridgei in China encompassed the length of the Gaoligong Mountains, based on a single male specimen collected in the Dulong valley in 1974. Ma \& Wang (1988) estimated the total population size to be $500-600$ individuals in the Dulong valley, but provided little detail of how these estimates were made. Wang (1998) confirmed the presence of T. shortridgei on the eastern slopes of the Gaoligong Mountains west of the $\mathrm{Nu}$ River, and Xu (1998) estimated these populations comprised 200300 individuals in 8-10 groups. The latest estimate indicated a total population in China of c. 250 individuals, with $<1,500$ $\mathrm{km}^{2}$ of suitable habitat (Forestry Department of Yunnan Province, 2001).

The presumed range of $T$. shortridgei spans a mostly contiguous forest ecosystem that includes northern Kachin State, Myanmar and the Dulong and Nu River valleys (Htun et al., 2008). The low human population and inaccessibility of the region have protected its biodiversity (Myers et al., 2000; Mittermeier et al., 2004); however, the region is beleaguered by an increasing number of environmental and socio-economic problems relating to poverty, civil unrest, illegal logging, smuggling of wildlife, drug trafficking, and hydro-development (Xu \& Wilkes, 2004; Kahrl 
et al., 2005; EIA, 2012; Wang et al., 2013; Burma Rivers Network, 2014). Identifying and quantifying some of the threats to biodiversity in the region, and impediments to its protection, specifically in relation to $T$. shortridgei, will facilitate better-informed management decisions. We therefore determined the distribution and population size of T. shortridgei in China as a benchmark for future monitoring, and report and evaluate local factors threatening the species. We propose practical strategies for local conservation actions and ecosystem protection.

\section{Study area}

We conducted the survey in the Dulong (Irrawaddy) and $\mathrm{Nu}$ (Salween) River catchments in north-west Yunnan Province in south-west China (Fig. 1). Both river systems have their headwaters on the Tibetan plateau and flow southwards, forming deeply incised parallel valleys flanked by mountain ranges $>5,000 \mathrm{~m}$. The topographic and climatic variation in the region results in a variety of natural habitat types, from subtropical broadleaved evergreen forest to high-alpine heath and meadows. Forests account for $>60 \%$ of the area (Weyerhaeuser et al., 2005). The climate is dominated by the East and South Asia monsoons, with precipitation occurring mostly in the warm season during May-October. Winter tends to be cool and dry throughout the region. As a result of its steep topographic and climatic gradients, and unique biogeography, the region has globally significant levels of biodiversity and endemism, with several distinct ecosystems (Myers et al., 2000; Mittermeier et al., 2004; UNESCO, 2014a).

The Dulong River and upper $\mathrm{Nu}$ River catchments are inhabited by members of $>10$ ethnic minority groups, including Dulong (also written as Drung), Lisu, $\mathrm{Nu}$ and Tibetan, who practise a variety of livelihood strategies, including small-scale agriculture, food and medicine gathering, transhumant grazing, swidden agriculture, trade, and hunting and trapping (Buntaine et al., 2007). Local economies and many livelihood strategies have changed as a result of infrastructue development, population growth, market shifts, and government subsidies and regulations, with both positive and negative impacts on biodiversity (Xu \& Wilkes, 2004; Weyerhaeuser et al., 2005). Strictly enforced bans on hunting and trapping in nature reserves and on the sale or trade of protected species have reduced market demand for many wildlife products; however, enforcement is difficult and illegal hunting is still widespread.

\section{Methods}

\section{Community interviews}

Community interviews can provide ecological information on threatened species, for conservation management
(Jones et al., 2008). Within the Dulong and Nu catchments we established a targeted area on the basis of information gleaned from park reports $(\mathrm{Xu}, 1998)$, historical reports (Ma et al., 1996), regional reserve managers, and visual assessment of satellite imagery for potential habitat (Ma et al., 2014). We conducted a series of interview surveys in the Dulong valley during 5-20 July 2010 and 7-25 November 2010, and west of the $\mathrm{Nu}$ River in the Gaoligong Mountains during 28 April-25 August 2012. Our interview subjects were mostly local people living in or near forests within the target search area. Interview subjects were identified through snowball sampling (Newing et al., 2011), beginning with the local leader in each village. We made a particular effort to select hunters and family elders with intimate, long-standing knowledge of the forest environment. We also interviewed numerous active forest patrollers and regional forest managers of Gaoligongshan National Nature Reserve. Interviews were brief, informal and unstructured (Xiang et al., 2007, 2009; Fan et al., 2011). During the interviews we tested whether respondents could describe morphological characteristics of T. shortridgei, and whether they could identify $T$. shortridgei correctly from pictures of local primates, including Trachypithecus pileatus, Trachypithecus phayrei, Rhinopithecus strykeri, Macaca arctoides, Macaca assamensis and Hoolock leucone$d y s$. If respondents could distinguish the species accurately we recorded all personal encounters with $T$. shortridgei, including time and date, location, group size, and group composition when possible.

During the interview survey period we also assessed the scope and magnitude of threats to T. shortridgei by gathering knowledge on the trapping success for T. shortridgei and other species, and on other community livelihood strategies that interact with the local habitat. As hunting and trapping protected species is illegal in China we recognized the sensitive nature of some interview data. Several approaches (e.g. the randomized response technique and the nominative technique) have been developed to collect data about illegal behaviour when perpetrators fear prosecution or repercussions (St. John et al., 2010). However, we found most communities were generally open and candid about historical hunting and trapping, and therefore we adopted a direct questioning approach (MacMillan \& Nguyen, 2014), supplementing the data with our visual observations of day-to-day activities. Before interviewing began in a village, each researcher generally lived with members of the community for several days, interacting with community members and reserve officers and participating in and learning about daily activities. This gave them time to develop a positive relationship with community members and identify interview candidates (Harris \& Shilai, 1997). The field research for the Dulong was conducted by YCL, who is ethnic Dulong, from the Dulong valley, and has strong ties with local community members. Interviews were usually 


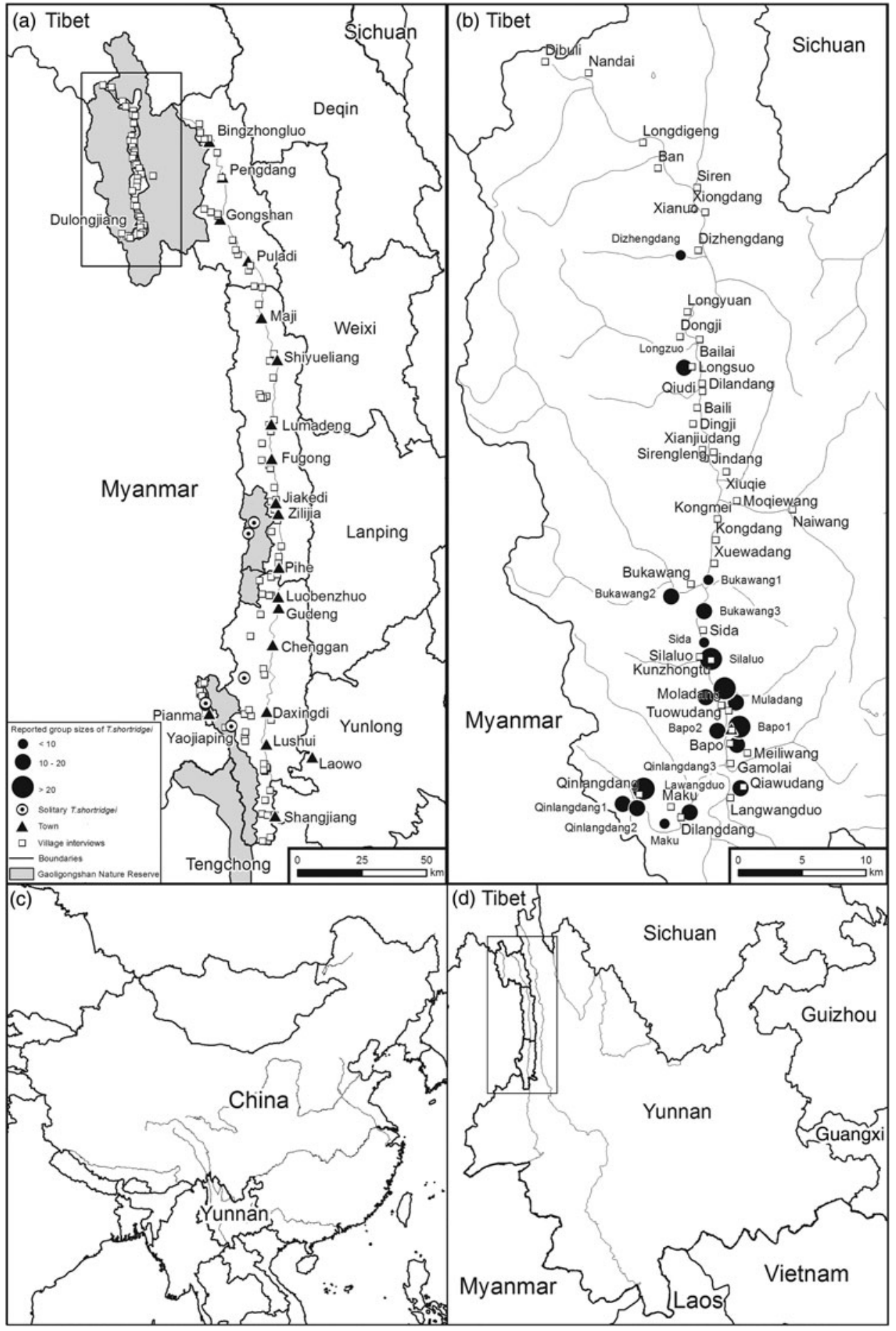

FIG. 1 Study area in north-west Yunnan province, China, with the locations of villages where local people were interviewed about Shortridge's capped langur Trachypithecus shortridgei, and locations where solitary langurs were observed (a), and the species' distribution and group sizes in the Dulongjiang Valley (b). The rectangle on (a) indicates the location of the Dulongiiang Valley in Gaoligongshan National Nature Reserve. The location of Yunnan Province in China is indicated in (c), and the rectangle on $(\mathrm{d})$ indicates the location of the study area in Yunnan. conducted in Mandarin Chinese, and if necessary in the Dulong (Drung) language in the Dulong valley; local translators assisted with interviews if the interview subjects only spoke another language.

\section{Field surveys}

To corroborate interview data we conducted field surveys in the southern Dulong valley, between Bukawang and Bapo, for
10 days each month during July 2012-July 2013 (130 days). We also carried out daily field surveys along the Gaoligong Mountains, near Pianma, Louzhang and Chengan in Lushui County, and near Zilijia and Lumadeng in Fugong County, during 22 September-2 December 2012 (47 days). We conducted all field survey work during the day (o8.0o17.00), recording the location, habitat type, and size and composition of groups of T. shortridgei encountered. The Dulong field surveys were conducted by one individual (YCL); two 
TABLE 1 Details of interviews conducted among local communities in the Nu and Dulong River valleys, Yunnan, China, during 20102012, with numbers of interview sites and subjects.

\begin{tabular}{|c|c|c|c|c|}
\hline \multirow[b]{2}{*}{ Catchment } & \multicolumn{2}{|c|}{ Interview sites } & \multicolumn{2}{|c|}{$\begin{array}{l}\text { Interview } \\
\text { subjects }\end{array}$} \\
\hline & Towns & Villages & Hunters & Total \\
\hline \multicolumn{5}{|l|}{ Dulong River valley } \\
\hline Gongshan County & 1 & 33 & 30 & 216 \\
\hline \multicolumn{5}{|l|}{$\mathrm{Nu}$ River valley } \\
\hline Gongshan County & 3 & 17 & 29 & 117 \\
\hline Fugong County & 7 & 30 & 69 & 195 \\
\hline Lushui County & 7 & 38 & 32 & 187 \\
\hline Total & 18 & 118 & 160 & 715 \\
\hline
\end{tabular}

6-7 person teams conducted the surveys in the Gaoligong Mountains. When possible we used local information and guides.

\section{Habitat change}

To estimate changes to T. shortridgei's core habitat in China we used satellite imagery to calculate changes in vegetation cover in the Dulong valley during 1975-2009. We downloaded satellite imagery (resolution $60 \times 60 \mathrm{~m}^{2}$ ) recorded in 1975, 1988, 2001, 2006 and 2009 (GIS Forum, 2012; NASA, 2012), and created visual interpretations using ArcGIS 9.2 (ESRI, Redlands, USA), categorizing vegetation into various land-cover types. For the purposes of this study we focused on vegetation categorized as (1) farmland, swidden agriculture and early seral scrubland, (2) secondary forest, or (3) mature native forest. We measured area, patch size and patch number for both forest types to make comparisons between years, as reported by Xiao et al. (2003) and Zhang et al. (2010). Visual interpretations of the satellite imagery were verified in the field. We performed a linear regression analysis of habitat change during 1975-2009, using Statistica 4.5 (Statsoft, Inc., Tulsa, USA), with a significance level of 0.05 .

\section{Results}

We interviewed 715 people (including 160 hunters) at 136 locations in north-west Yunnan (Table 1, Fig. 1); 693 were male, 22 were female, and the mean age of respondents was $50.2 \pm$ SD 15.6 years. Most people interviewed had lived and worked in and near the forest for $>30$ years. The most common reasons for entering the forests included collection of non-timber forest products and herbal medicine, and grazing.

From interviews in the Dulong River valley we identified 19 groups of T. shortridgei (estimated 250-370 individuals; Table 2). During field surveys we observed two groups
(Sida and Bukawang-3) repeatedly ( $>10$ times) in mixed evergreen and broadleaved forests near the river, around Bukawang and Sida villages. The Sida group consisted of seven individuals, and the Bukawang-3 group consisted of nine individuals (Table 2). Each group consisted of one adult male, 2-3 adult females and up to five juveniles.

Interview subjects in the Gaoligong Mountains in Gongshan, Lushui and Fugong Counties reported observations of 12 solitary individuals during 1975-2012 (Table 3). Each of these sightings was in low- to mid-elevation forests along the Gaoligong Mountains close to the border between China and Myanmar (Fig. 1), and all were in or near the Gaoligongshan National Nature Reserve. Our field surveys in the same region did not yield any positive observations of T. shortridgei.

Using remote sensing we estimated mature native forests in the Dulong valley decreased by $34.7 \%\left(424.5 \mathrm{~km}^{2}\right)$ during 1975-2009 $\left(F_{1,3}=13.31, R^{2}=0.82, \mathrm{P}=0.03\right.$; Table 4$)$. During the same period, mean forest patch size decreased from 978.3 to 276.1 ha, the number of forest patches increased from 125 to 289 , and the area of swidden agriculture and seral scrubland increased by $254.7 \mathrm{~km}^{2}$ (Table 4). However, during 2001-2009 total forest cover increased by $80.4 \mathrm{~km}^{2}$, and swidden agriculture and seral scrubland decreased by $180.5 \mathrm{~km}^{2}$ (Table 4 ).

Illegal destruction of forest habitat has taken place both inside and outside the boundaries of the Reserve. Forest has been felled for fuelwood and building materials, and to clear land for livestock grazing, gardens, and cultivation of economic crops such as black cardamom Amomum tsao-ko, walnut Juglans regia, chestnut Castanea mollissima, sumac Toxicodendron vernicifluum and black pepper Piper nigrum.

Records of hunting and trapping of wild animals in the Dulong valley are in Table 5 . Twelve T. shortridgei were reported killed since the 1970s (one was kept as a pet). Seven other species were also reported to be killed or kept as pets; the species killed in greatest abundance were takin Budorcas taxicolor taxicolor (23) and red muntjac Muntiacus muntjak (12). Food was the most common motivation for killing T. shortridgei and other wildlife, according to interview subjects, although cash income was also reported as a primary motivation (Table 5).

Most T. shortridgei were killed using traditional crossbows, typically constructed of an oak or bamboo wood prod and an oak stock. Arrows were typically c. $25-30 \mathrm{~cm}$ in length, made from bamboo, and often tipped with a paste from the poisonous dried root of Aconitum sp. (Ranunculaceae).

The most common method used to kill wildlife was trapping (Table 5). Trap types used included steel-jaw leg-hold traps and simple snares. Steel traps $(18 \mathrm{~cm}$ diameter $)$ intended primarily to catch bears were commonly used by hunters in the Dulong valley, and were observed at a density of c. $14 \mathrm{ha}^{-1}$ in the forest (YCL, pers. obs.). Smaller steel traps (10 cm diameter) for catching small mammals and 
TABLE 2 Details of Trachypithecus shortridgei groups in the Dulong valley in north-west Yunnan, China (Fig. 1), based on direct observations $\left({ }^{*}\right)$ and interviews with local people, with site, group size, number of witnesses, and date of detection.

\begin{tabular}{lccl}
\hline Site & Group size & No. of witnesses & Date of detection \\
\hline Qinlangdang-1 & $10-20$ & 3 & Oct. 2010 \\
Qinlangdang-2 & $10-20$ & 4 & 2009 \\
Qinlangdang-3 & $\geq 30$ & 3 & May 2009, June-July 2010 \\
Maku & $\mathrm{c} .10$ & 5 & Nov. 2011 \\
Dilangdang & $10-20$ & 4 & Aug. 2010, Nov. 2010 \\
Lawangduo & $10-20$ & 2 & $2004-2007$ \\
Maoding & $10-20$ & 4 & 1980 s, 2005-2006 \\
Bapo-1 & $20-30$ & 6 & 1980 s, 1990s, 1996, Mar. 2012 \\
Bapo-2 & $10-20$ & 8 & $1999,2007-2010$, May 2012 \\
Muladang & $10-20$ & 5 & Apr.-May \& Nov. 2009 \\
Meilimen & $10-20$ & 7 & 1990 s, 2007-2009, Jan. 2013 \\
Mabidang & $\geq 30$ & 8 & $2005-2006,2010$, Dec. 2012 \\
Silaluo & $20-30$ & 7 & $2006-2007,2009-2010$, Dec. 2012 \\
Sida* & 9 & 1 & July-Dec. 2012 \\
Bukawang-3* & 7 & 15 & July-Dec. 2012 \\
Bukawang-2 & $10-20$ & 5 & $2007-2008,2012$ \\
Bukawang-1 & c. 10 & 8 & $2008-2009,2012$ \\
Longzuo & $10-20$ & 2 & 1980 s, Nov. 2004, Mar. 2005, 2010 \\
Dizhengdang & c. 10 & 1 & $1980 s, 2002$ \\
Total & $250-370$ & 98 & \\
\hline
\end{tabular}

TABLE 3 Sightings of T. shortridgei in the Gaoligong Mountains, west of Nu River, north-west Yunnan, reported in interviews with members of local communities, with village, number of witnesses, activity, date, and number of individuals observed.

\begin{tabular}{lllll}
\hline Village (County) & No. of witnesses & Activity & Date & No. of individuals observed \\
\hline Lamujia (Fugong) & 1 & Hunting & 1975 & 1 \\
Jinxiugugada (Fugong) & 2 & Logging & 2005 & 1 \\
Pianma (Lushui) & 3 & Travelling & Apr. 2012 & 1 \\
Luoji (Lushui) & 2 & Patrolling & Apr. 2009 & 1 \\
Gulang (Lushui) & 1 & Hunting & Unsure & 1 \\
Pianma (Lushui) & 2 & Walking to town & May-June 2012 & 1 \\
Pianma (Lushui) & 1 & Quarrying & Jan. 2012 & 1 \\
Pianma (Lushui) & 3 & Travelling & Jan. 2012 & 1 \\
Pianma (Lushui) & 2 & Returning from Pianma & June 2004 & 1 \\
Pianma (Lushui) & 5 & Quarrying & Apr. 2012 & 1 \\
Paiba (Lushui) & 1 & Collecting Chinese medicine & June 1997 & 1 \\
Yaojiaping (Lushui) & 4 & Travelling & Sep. 2012 & 1 \\
\hline
\end{tabular}

Galliformes were observed at a density of c. $10 \mathrm{ha}^{-1}$ (YCL, pers. obs.). Snares were usually set to catch muntjacs, small mammals and Galliformes. Snare trap density was observed to be c. $1.5 \mathrm{ha}^{-1}$ (YCL., pers. obs.); however, snares are, by design, difficult to detect, and some local people in the Dulong valley claimed they were at a density of $10 \mathrm{ha}^{-1}$ in some places. Typically snares were set using a combination of basic, readily available purchased material and natural material found near the trap site, and were power activated (a tensioned tree or branch connected by lianas, twine or steel cables to a trigger mechanism, usually a small piece of twig or bamboo, and secured to an anchored twig or sapling stump). Traps and snares were typically set along animal paths in places with natural channelling in the vegetation, or using brush and bamboo sticks to funnel animal movement. Small steel traps were often used in tree cavities, to catch arboreal rodents, such as squirrels. Traps and snares were rarely baited.

Some animals were shot with small-calibre muzzleloading rifles, which seemed to be used more often for extended hunting expeditions away from village centres. Personal firearms are illegal in China, with severe penalties, thus unsurprisingly most people were reluctant to discuss the prevalence of rifles. In 2013, 1 year after our interviews, 22 rifles were confiscated by local authorities in the Dulong valley. 
TABLE 4 Area, mean patch size, and number of patches of land covered by native forests, secondary forests, and swidden agriculture and seral scrub in the Dulong valley during 1975-2009.

\begin{tabular}{|c|c|c|c|c|c|}
\hline Land cover & 1975 & 1988 & 2001 & 2006 & 2009 \\
\hline \multicolumn{6}{|l|}{ Area $\left(\mathrm{km}^{2}\right)$} \\
\hline Native forests & $1,222.0$ & 956.0 & 739.1 & 867.7 & 797.5 \\
\hline Secondary forests & 32.9 & 93.6 & 80.5 & 87.6 & 102.5 \\
\hline Swidden agriculture \& seral scrub & 109.2 & 346.3 & 544.4 & 400.6 & 363.9 \\
\hline \multicolumn{6}{|l|}{ Mean patch size (ha) } \\
\hline Native forests & 978.3 & 255.6 & 116.2 & 176.4 & 276.1 \\
\hline Secondary forests & 10.7 & 27.5 & 15.4 & 7.8 & 18.2 \\
\hline Swidden agriculture \& seral scrub & 13.1 & 37.4 & 3.2 & 3.0 & 3.91 \\
\hline \multicolumn{6}{|l|}{ No. of patches } \\
\hline Native forests & 125 & 374 & 636 & 492 & 289 \\
\hline Secondary forests & 308 & 340 & 522 & 1,128 & 562 \\
\hline Swidden agriculture \& seral scrub & 835 & 930 & 858 & 939 & 949 \\
\hline
\end{tabular}

\section{Discussion}

We learned that in China the Endangered Shortridge's capped langur is limited mainly to the Dulong River valley, with a population of 250-370 individuals in 19 groups (Table 2, Fig. 1). Groups are generally structured around family groups comprising one male, two or more females and their immature offspring. Based on comparison with earlier estimates of 500-600 individuals in the Dulong valley (Ma \& Wang, 1988) the population appears to have declined; however, the methods used by Ma \& Wang (1988) are unclear, making comparisons tenuous. We also learned from interviews that there are unlikely to be any viable populations of the species in China outside the Dulong valley. $\mathrm{Xu}$ (1998) estimated the population in that area to be 200300 individuals in 8-10 groups, whereas we recorded only a few isolated sightings of solitary individuals. Although again the methods of $\mathrm{Xu}$ (1998) are unclear, the results indicate that the population in the Dulong valley has declined substantially.

The population decline is probably attributable to various factors, in particular in relation to habitat change and hunting pressure. The Gaoligongshan National Nature Reserve was established in 1983 but for many years its boundaries were not clearly defined and regulations were poorly disseminated and rarely enforced. Tighter controls and strict regulations introduced in 1989 resulted in a sense of grievance and dissociation among local people in relation to the Reserve. Communities whose villages, cropland and traditional hunting and gathering grounds were designated within the boundary of the Reserve were subject to involuntary displacement and resettlement. Many people resist compliance, and continue to occupy traditional farm plots within the Reserve, subsidizing resource requirements with non-timber forest products, wood gathering, and hunting. In some parts of China forest felling has increased in the initial period after the establishment of a National Park, as people abandon more sustainable practices when land tenure is uncertain (Liu et al., 2001). Cash crops, fuelwood collection and forest clearance affect forest structure, fragmenting forest habitat, and reducing and altering the habitat available to wildlife (Li, 2004; Bearer et al., 2008; Yuan et al., 2014).

Large-scale government projects have also had a significant impact on local communities, their management of natural resources and their interactions with wildlife. In response to floods in the lower Yangtze in 1998, the central government announced the National Forest Protection Programme in 2000, banning logging in the upper reaches of the Yangtze and Yellow River catchments as a watershed protection measure. Restrictions on forest felling were subsequently applied elsewhere, including the $\mathrm{Nu}$ and Dulong catchments. In conjunction with this programme the government also launched the Sloping Land Conversion Programme, to convert erodible cropland with slopes $>25^{\circ}$ to forest and grassland (SFA, 2003). In return, farmers received subsidies in the form of cash or grain. The impacts of these programmes on local people have caused concern (Kahrl et al., 2005; Weyerhaeuser et al., 2005; Shen et al., 2010). Many households struggle to produce enough food to meet their needs, and turn to income-generating activities such as collecting non-timber forest products and illegal hunting (Xu \& Wilkes, 2004). Despite these concerns government-led projects to arrest rates of deforestation are necessary to protect habitat for primary forest species. In the Dulong River catchment forests were reduced by $40 \%$ during 1975-2001 but recovered by 8\% during 2001-2009 following government intervention. Although most ecosystems in China have long been affected by human interventions, the Dulong and Nu River valleys have been sparsely populated throughout human history, and human impacts on the natural forest ecosystem have been relatively small and localized, evolving with the use of imported technologies and crops (Chu, 2006). Population growth and 
TABLE 5 Events of killing, trapping or smuggling of wildlife reported in community interviews in the Dulong valley, in north-west Yunnan, with number of individuals of each species, the site where the event occurred, event, and motivation.

\begin{tabular}{|c|c|c|c|c|}
\hline No. of individuals & Date & Site & Event & Motivation \\
\hline \multicolumn{5}{|c|}{ Shortridge's capped langur Trachypithecus shortridgei } \\
\hline 1 & $1970 \mathrm{~s}$ & Longyuan & Killed & Food \\
\hline 1 & $1980 \mathrm{~s}$ & $\begin{array}{l}\text { Atuluo valley at } \\
\text { Longyuan }\end{array}$ & Caught with steel trap, killed & Food \\
\hline 1 & $1990 \mathrm{~s}$ & Muladang & Shot with gun, killed & Research specimen \\
\hline 1 & $1990 \mathrm{~s}$ & Serutu & Shot with crossbow, killed & Food \\
\hline 3 & Mar. 1996 & Valley near Silalu & Shot with crossbow, killed & Food \\
\hline 1 & 2011 & Serutu & $\begin{array}{l}\text { Caught with steel trap, killed, } \\
\text { confiscated by police }\end{array}$ & Food or sale \\
\hline 1 & Mar. 2012 & Lawangduo & $\begin{array}{l}\text { Infant captured by hand, reared } \\
\text { for a while \& then died }\end{array}$ & Pet \\
\hline 2 & Apr. 2012 & Lawangduo & $\begin{array}{l}\text { Shot with poison-tipped arrows } \\
\text { from crossbow, } 1 \text { adult female } \\
\text { \& } 1 \text { infant killed, } 7 \text { injured }\end{array}$ & Food \\
\hline 1 & May 2012 & South of Bukawang & $\begin{array}{l}\text { Caught \& injured with steel trap } \\
\text { (1 adult female), rescued by } \\
\text { Nature Reserve staff }\end{array}$ & Food \\
\hline 1 & May 2012 & $\begin{array}{l}\text { Valley between Maku } \\
\text { \& Qinglangdang }\end{array}$ & $\begin{array}{l}\text { Smuggled from Myanmar } \\
\text { (1 adult female), released into } \\
\text { a valley between Maku \& } \\
\text { Qinglangdang }\end{array}$ & Sale \\
\hline 1 & Sep. 2012 & Forest near Sida & Shot with gun, killed & Sale \\
\hline 1 & Oct. 2012 & Muladang & Killed & Food or sale \\
\hline \multicolumn{5}{|c|}{ Takin Budorcas taxicolor taxicolor } \\
\hline 20 & $2005-2008$ & Mudang & $\begin{array}{l}\text { Shot with guns \& caught with } \\
\text { steel traps \& snares, killed }\end{array}$ & Food or sale \\
\hline 3 & 2012 & $\begin{array}{l}\text { Xianjiudang, } \\
\text { Qinlangdang }\end{array}$ & Killed & Food or sale \\
\hline \multicolumn{5}{|c|}{ Long-tailed goral Naemorhedus caudatus } \\
\hline 3 & 2012 & $\begin{array}{l}\text { Longyuan, } \\
\text { Mulandang }\end{array}$ & $\begin{array}{l}\text { Shot with gun (1) \& caught } \\
\text { with steel traps (2), killed }\end{array}$ & Food \\
\hline \multicolumn{5}{|c|}{ Red panda Ailurus fulgens } \\
\hline 5 & 2012 & Mt. Bidang & Caught with steel traps, killed & Unknown \\
\hline \multicolumn{5}{|c|}{ Asian black bear Ursus thibetanus } \\
\hline 2 & 2012 & Lapei & $\begin{array}{l}\text { Shot with gun (1) \& with } \\
\text { crossbow (1), killed }\end{array}$ & Food \\
\hline \multicolumn{5}{|c|}{ Rhesus macaque Macaca mulatta } \\
\hline 2 & $2012-2013$ & $\begin{array}{l}\text { Longyang, } \\
\text { Qinlangdang }\end{array}$ & $\begin{array}{l}\text { Caught by hand (1) \& with } \\
\text { steel trap (1) }\end{array}$ & Pet \\
\hline \multicolumn{5}{|c|}{ Assam macaque Macaca assamensis } \\
\hline 3 & 2012 & Sida & Caught with snares & Pet \\
\hline \multicolumn{5}{|c|}{ Red muntjac Muntiacus muntjak } \\
\hline 12 & 2013 & $\begin{array}{l}\text { Lawangduo, } \\
\text { Kongdang }\end{array}$ & $\begin{array}{l}\text { Shot with crossbow (2) \& caught } \\
\text { with steel trap (10), killed }\end{array}$ & Food or sale \\
\hline
\end{tabular}

infrastructural development, such as roads and hydroprojects, which themselves bring an influx of tradespeople and new settlers to the area, will further exacerbate the demand for resources and impose a high-resource-use economy on local people (Xu et al., 2005). Similar-sized projects in Myanmar, such as the Irrawaddy/N'Mai hydro schemes (Burma Rivers Network, 2014), along with rapid deforestation (Global Witness, 2009), will probably have a negative effect on langur populations there. Road development will increase mobility, potentially facilitating the wildlife trade (Suárez et al., 2009).

Our results also indicated that Shortridge's capped langur is threatened by hunting in the Dulong valley and is unlikely to re-establish populations in the Gaoligong Mountains unless changes occur in cultural practices and park management. Most langurs killed in the Dulong valley were reportedly shot for food. Most hunters have an indepth knowledge of the local wildlife, and therefore it is 
unlikely that the langurs were shot by mistake, suggesting that hunters target langurs. Twenty percent of the medium/large mammals reported killed were Shortridge's langurs (Table 5). Reports of Shortridge's capped langurs being smuggled from Myanmar, where wildlife laws are largely unregulated and punishment is less severe than in China (Martin \& Redford, 2000; Xu \& Wilkes, 2004; Shepherd \& Nijman, 2008; this study), suggest there is an increasing and lucrative illegal market for the species. Eleven T. shortridgei individuals smuggled into China from Myanmar were confiscated during 1999-2004, and 10 were confiscated during 2004-2009 (Lei, 1999; Wen, 2004; Wu, 2005; Zhang, 2009).

With increasing focus on regulation of firearms, there is concern that people may turn to trapping instead (Li \& Jiang, 2014). Traps and snares are difficult to detect, regulate and monitor (Li \& Jiang, 2014), and the materials are cheap and accessible, traps can be well concealed, and personal accountability is less than for guns or crossbows. The main concern is that traps are less targeted and may affect multiple species. We observed snares and traps capable of killing langurs set at densities $>10 \mathrm{ha}^{-1}$.

Based on what we learned through interviews and engagement with communities we conclude that several actions are required to protect Shortridge's capped langur. Firstly, we recommend an independent systematic review of the management strategy for Gaoligongshan National Nature Reserve. North-western Yunnan is a region of global importance for biodiversity (Myers et al., 2000; Stotz et al., 2003; Mittermeier et al., 2004; UNESCO, 2014a,b) and has at least 10 resident ethnic groups, and therefore the management of the Reserve will require a unique approach, requiring critical thought. We suggest the review examines the successes and shortcomings of the current system, and considers more integrative management, community involvement, and alternative methods for nature conservation (Xu et al., 2005; Xu \& Melick, 2007). We suggest a comprehensive census of non-threatened populations of fauna and non-timber forest products, which may in future allow some concession for traditional hunting or gathering practices. We also suggest mapping the traditional extent of swidden agriculture and grazing, to delineate human agricultural practices in the region over time and support a management strategy that incorporates human interactions with the environment.

The feeling of dissociation from, or resentment towards, the objectives of the Reserve among local people is a significant threat to the survival of T. shortridgei and other species in the region. There is little incentive for local people to obey the laws or nurture what is inside the Reserve. Many people are dissatisfied with their position in society and will risk prosecution for short-term economic gains. We support maintaining strict prohibition of killing or trading threatened species, and maintaining absolute limits to forest clearance (and increasing enforcement in these areas), but we also see a good case for leniency for small-scale swidden agriculture and wood collection, and possibly even targeted hunting using only traditional crossbows in designated areas, to support livelihood needs and well-being, maintain cultural identities, and foster good communication and stewardship in the local communities. This strategy is being piloted in several National Parks in Vietnam (MacMillan \& Nguyen, 2014). The trade-off would be a ban on all guns, traps of all types, and the sale of any wild animal. Degraded forests can gradually recover and increase their potential for sustaining threatened species (Bearer et al., 2008) but recovery will be dependent on local cooperation.

Another important factor in species protection is education. We suggest that local knowledge of the forest, agriculture and culture needs to be maintained, and integrated with current ecological knowledge. People must be made aware of the rarity of certain species, and their food and habitat requirements. Many people have a parochial view of forest species and fail to realize that a species that is common locally could be absent elsewhere (M. Scott, unpubl. data). In some parts of north-western Yunnan, religio-cultural beliefs effectively protect biodiversity (Xue, 2009). However, in the Dulong and $\mathrm{Nu}$ valleys many groups (e.g. Dulong, Lisu, $\mathrm{Nu}$ ) with animistic beliefs have few restrictions or taboos associated with hunting (Harris \& Shilai, 1997). These ethnic groups believe that animals are bestowed by deities, and successful hunters are considered lucky. Among these groups, education could be an effective mechanism to protect species and gain compliance with regulations (Harris \& Shilai, 1997).

Inconsistency in enforcement of wildlife law is another impediment to protection. We recommend capacitybuilding projects to increase the knowledge of Reserve staff, develop professionalism, and train staff to collect ecological data. We also think it is important to establish an effective cooperation mechanism between Myanmar and China to stop illegal smuggling of wildlife. It may be necessary to employ more local rangers tasked specifically with patrolling and monitoring groups of T. shortridgei, clearing illegal traps, educating local people on the legalities of hunting and trapping, and enforcing compliance.

\section{Acknowledgements}

This study was supported by Yunnan Green Environmental Development Fund, a central financial assistance fund for capacity-building of Gaoligongshan Nature Reserve, National Natural Science Foundation of China (\#31160422, \#30960084), Programme for New Century Excellent Talents in University (NCET-12-1079), the China Postdoctoral Science Foundation (2013M542379), and Key Subject of Wildlife Conservation and Utilization in Yunnan Province. 
We thank Nujiang Administrative Bureau of Gaoligongshan Nature Reserve for their support, and Yang XG, Yang SJ and Dong $\mathrm{XH}$ for their assistance in the field.

\section{References}

Bearer, S., Linderman, M., Huang, J.Y., An, L., He, G.M. \& Liu, J. G. (2008) Effects of fuelwood collection and timber harvesting on giant panda habitat use. Biological Conservation, 141, 385-393.

Buntaine, M.T., Mullen, R.B. \& Lassoie, J.P. (2007) Human use and conservation planning in alpine areas of northwestern Yunnan, China. Environment, Development and Sustainability, 9, 305-324.

Burma Rivers Network (2014) Irrawaddy/N'Mai/Mali Dams. Http://burmariversnetwork.org/index.php/dam-projects/ irrawaddynmaimali [accessed 20 November 2014].

Chu, F.G. (ed.) (2006) Ethnic Dulong and Nu County Annals. Nationality Press, Kunming, China. [In Chinese]

CITES (2014) Convention on International Trade in Endangered Species of Wild Fauna and Flora. Appendices I, II and III. Http://www.cites. org/eng/app/appendices.php [accessed 20 November 2014].

Eia (Environmental Investigation Agency) (2012) Appetite for Destruction: China's Trade in Illegal Timber. Unpublished report. Environmental Investigation Agency, London, UK.

FAN, P.F., XIAO, W., HoU, S., AI, H.S., WANG, T.C. \& LiN, R.T. (2011) Distribution and conservation status of the Vulnerable eastern hoolock gibbon Hoolock leuconedys in China. Oryx, 45, 129-134.

Forestry Department of Yunnan Province (ed.) (2001) Survey Report on Terrestrial Vertebrates in Yunnan. Unpublished report. Forestry Department of Yunnan Province, Kunming, China. [In Chinese]

GIS FORUM (2012) Http://www.gisforum.net

Global Witness (2009) A Disharmonious Trade: China and the Continued Destruction of Burma's Northern Frontier Forests. Unpublished report. Global Witness, London, UK.

Groves, C.P. (2001) Primate Taxonomy. Smithsonian Institution Scholarly Press, Washington, DC, USA.

HARRIS, R.B. \& ShILAI, M. (1997) Initiating a hunting ethic in Lisu villages, western Yunnan, China. Mountain Research and Development, 17, 171-176.

Htun, S., Long, Y.C. \& Richardson, M. (2008) Trachypithecus shortridgei. In The IUCN Red List of Threatened Species v. 2013.2. Http://www.iucnredlist.org [accessed 20 November 2014].

Jones, J.P.G., Andriamarovololona, M.M., Hockley, N., Gibbons, J.M. \& Milner-Gulland, E.J. (2008) Testing the use of interviews as a tool for monitoring trends in the harvesting of wild species. Journal of Applied Ecology, 45, 1205-1212.

Kahrl, F., Weyerhaeuser, H., Su, Y.F. (2005) An Overview of the Market Chain for China's Timber Product Imports from Myanmar. Unpublished report. Forest Trends, Washington, DC, USA.

LEI, Y.B. (1999) Shortridge's Langurs (Trachypithecus shortridgei) Rescued in Yunnan. Http://www.envir.gov.cn/info/np/file.asp?file= 998-21-40.txt [accessed 3 February 2015]. [In Chinese]

LI, X.Y. \& JIANG, X.L. (2014) Implication of musk deer (Moschus spp.) depletion from hunter reports and dung transect data in northwest Yunnan, China. Journal for Nature Conservation, 22, 474-478.

LI, Y.M. (2004) The effect of forest clear-cutting on habitat use in Sichuan snub-nosed monkey (Rhinopithecus roxellana) in Shennongjia Nature Reserve, China. Primates, 45, 69-72.

LI, Z.X. \& LiN, Z.Y. (1983) Classification and distribution of living primates in Yunnan, China. Zoological Research, 4, 111-119. [In Chinese]
Liu, J., Linderman, M., Ouyang, Z., An, L., Yang, J. \& Zhang, H. (2001) Ecological degradation in protected areas: the case of Wolong Nature Reserve for giant pandas. Science, 292, 98-101.

Ma, C., Huang, Z.P., Zhao, X.F., Zhang, L.X., Sun, W.M., Sсотt, M.B. et al. (2014) Distribution and conservation status of Rhinopithecus strykeri in China. Primates, 55, 377-382.

MA, S.L., HAN, L.X. \& Chen, Z.P. (1996) Birds and mammals of the Dulongjiang Valley. In Synthetic Research of Ethnic Dulong and the Dulongjiang (eds D.M. He \& H. Li), pp. 41-54. Yunnan Science and Technology Press, Kunming, China. [In Chinese]

MA, S.L. \& WANG, Y.X. (1988) The recent distribution, status and conservation of primates in China. Acta Theriologica Sinica, 8, 250260. [In Chinese]

MacMillan, D.C. \& NGUyen, Q.A. (2014) Factors influencing the illegal harvest of wildlife by trapping and snaring among the Katu ethnic group in Vietnam. Oryx, 48, 304-312.

Martin, E. \& Redford, T. (2000) Wildlife for sale. Biologist, 47, 27-30. Mittermeier, R.A., Robles Gil, P., Hoffmann, M., Pilgrim, J.D., Brooks, T.M., Mittermeier, C.G. \& Da Fonseca, G.A.B. (2004) Hotspots Revisited: Earth's Biologically Richest and Most Endangered Ecoregions. CEMEX, Mexico City, Mexico.

Myers, N., Mittermeier, R.A., Mittermeier, C.G., Da Fonseca, G.A.B. \& Kent, J. (2000) Biodiversity hotspots for conservation priorities. Nature, 403, 853-858.

NASA (2012) Http://landsat.gsfc.nasa.gov/

Newing, H., Eagle, C.M., Puri, R.K. \& Watson, C.W. (2011) Conducting Research in Conservation: A Social Science Perspective. Routledge, Abingdon, UK.

Pocock, R.I. (1939) The Fauna of British India, Including Ceylon and Burma. Mammalia-Vol. I, Primates and Carnivora (in part). Taylor and Francis, London, UK.

SFA (State Forest Administration) (2003) Masterplan for the Sloping Land Conversion Programme. State Forest Administration, Beijing, China.

Shen, S.C., Wilkes, A., Qian, J., Yin, L., Ren, J. \& Zhang, F.D. (2010) Agrobiodiversity and biocultural heritage in the Dulong valley, China: impacts of and responses to the Sloping Land Conversion Program. Mountain Research and Development, 30, 205-211.

Shepherd, C.R. \& Nijman, V. (2008) Elephant and Ivory Trade in Myanmar. TRAFFIC Southeast Asia, Selangor, Malaysia.

St. John, F.A.V., Edwards-Jones, G., Gibbons, J.M. \& Jones, J.P.G. (2010) Testing novel methods for assessing rule breaking in conservation. Biological Conservation, 143, 1025-1030.

Stotz, D.F., Harris, E.J., Moskovits, D.K., Hao, K., Yi, S.L. \& Adelmann, G.W. (eds) (2003) China: Yunnan, Southern Gaoligongshan. Rapid Biological Inventories Report No. 04. Unpublished report. The Field Museum, Chicago, USA.

Suárez, E., Morales, M., Cueva, R., Utreras Bucheli, V., Zapata-Ríos, G., Toral, E. et al. (2009) Oil industry, wild meat trade and roads: indirect effects of oil extraction activities in a protected area in north-eastern Ecuador. Animal Conservation, 12, 364-373.

UNESCO (2014a) Three Parallel Rivers of Yunnan Protected Areas. Http://whc.unesco.org/en/list/1083 [accessed 24 December 2014].

UNESCO (2014b) Biosphere Reserve Information: Gaoligong Mountain. Http://www.unesco.org/mabdb/br/brdir/directory/ biores.asp? code $=C P R+18 \&$ mode $=$ all [accessed 24 December 2014].

Wang, P., Wolf, S.A., Lassoie, J.P. \& Dong, S.K. (2013) Compensation policy for displacement caused by dam construction in China: an institutional analysis. Geoforum, 48, 1-9.

WAng, Y.X. (1998) Trachypithecus pileatus. In China Red Data Book of Endangered Animals (Mammalian) (ed. S. Wang), pp. 72-73. Science Press, Beijing, China. [In Chinese] 
Wen, B. (2004) Who is Making the Monkeys Go Extinct in China? Http://www.people.com.cn/GB/huanbao/1074/2399605.html [accessed 3 February 2015]. [In Chinese]

Weyerhaeuser, H., Wilkes, A. \& Kahrl, F. (2005) Local impacts and responses to regional forest conservation and rehabilitation programs in China's northwest Yunnan province. Agricultural Systems, 85, 234-253.

Wroughton, R. (1915) The mammal survey. No. XII. A. On the Squirrels obtained by Messrs. Shortridge and Macmillan on the Chindwin River, Upper Burma. Journal of the Bombay Natural History Society, 24, 42-46.

Wu, Y.Y. (2005) A Case of Capturing and Smuggling Wild Animals was Investigated and Solved on 18 August 2005. Http://www.baoshan.cn/ 4034/2005/11/09/707@283798.htm [accessed 3 February 2015]. [In Chinese]

Xiang, Z.F., Nie, S.G., Lei, X.P., Chang, Z.F., Wei, F.W. \& Li, M. (2009) Current status and conservation of the gray snub-nosed monkey Rhinopithecus brelichi (Colobinae) in Guizhou, China. Biological Conservation, 142, 469-476.

Xiang, Z.F., Wang, L., Huo, S., Cui, L.W., Xiao, W., Quan, R.C. \& Zhong, T. (2007) Distribution, status and conservation strategies of the black-and-white snub-nosed monkey Rhinopithecus bieti in Tibet. Oryx, 41, 525-531.

Xiao, W., Ding, W., Cui, L.W., Zhou, R.L. \& ZhaO, Q.K. (2003) Habitat degradation of Rhinopithecus bieti in Yunnan. International Journal of Primatology, 24, 389-398.

Xu, J.C. \& Wilkes, A. (2004) Biodiversity Impact Analysis in Northwest Yunnan, Southwest China. Biodiversity and Conservation, 13, 959-983.

Xu, J.C., MA, E., Tashi, D.J., Fu, Y.S., Lu, Z. \& Melick, D. (2005) Integrating sacred knowledge for conservation: cultures and landscapes in southwest China. Ecology and Society, 10, 7.

XU, J.C. \& MELICK, D.R. (2007) Rethinking the effectiveness of public protected areas in southwestern China. Conservation Biology, 21, $318-328$.
Xu, Z.H. (ed.) (1998) Nujiang Nature Reserve. Yunnan Art Press, Kunming, China. [In Chinese]

Xue, D.Y. (ed.) (2009) Traditional Culture and Biodiversity Conservation in Ethnic Areas of China. Chinese Environmental Science Press, Beijing, China.

Yuan, S.D., Fei, H.L., Zhu, S. H., CuI, L.W., Ai, H.S. \& Fan, P.F. (2014) Effect of tsaoko (Fructus tsaoko) cultivating on tree diversity and canopy structure in the habitats of eastern hoolook gibbon (Hoolock leuconedys). Zoological Research, 35, 231-239.

Zhang, M.X., Fellowes, J.R., Jiang, X.L., Wang, W., Chan, B.P.L., ReN, G.P. \& ZHU, J.G. (2010) Degradation of tropical forest in Hainan, China, 1991-2008: conservation implications for Hainan gibbon (Nomascus hainanus). Biological Conservation, 143, 13971404.

ZHANG, Y.Q. (2009) A Case of Smuggling Wildlife was Investigated in Kunming. Http://news.xinhuanet.com/legal/2009-06/12/content_ 11532569.htm [accessed 3 February 2015]. [In Chinese]

\section{Biographical sketches}

LIANG -WE I CUI studies behavioural ecology and conservation biology of threatened primates. YING-CHUN LI and JIN-FA LI are studying the foraging behaviour and habitat use of Trachypithecus shortridgei. CH I MA is studying the foraging behaviour of Trachypithecus phayrei and the impacts of tsaoko cardamom production on habitat use in Gaoligong Nature Reserve. MAт тнеw B. Sсот т has broad interests in conservation biology and the interaction between resource users and wildlife. XIAO-YANG He, Dong-Hui Li and Jun Sun are responsible for the management of nature reserves in the $\mathrm{Nu}$ and Dulong River valleys, and local community education. WEN-MO SUN is interested in applying geospatial techniques to wildlife conservation. WEN XI A o has broad interests in conservation biology and wildlife ecology, and is studying how human-related changes to the environment affect wild animal populations. 